\title{
AMMONICAL - NITROGEN REMOVAL BY AN AEROBIC HETEROTROPHIC BACTERIUM, Microbacterium sp., VCM11
}

\author{
Muthukrishnan, S. , Sabaratnam, V. ${ }^{1,2}$, and Chong V.C. ${ }^{1,3, *}$ \\ ${ }^{1}$ Institute of Biological Sciences, University of Malaya, 50603 Kuala Lumpur \\ ${ }^{2}$ Mushroom Research Centre, University of Malaya, 50603 Kuala Lumpur \\ ${ }^{3}$ Institute of Oceanography and Earth Sciences, University of Malaya, 50603 Kuala Lumpur \\ *Email: chong@um.edu.my (corresponding author)
}

\begin{abstract}
Bacterial strains were isolated from shrimp culture wastewater and assessed for ammonia reduction activity. Nine strains were selected based on nitrate reduction test. Out of nine strains, VCM11 showed significant $(\mathrm{p} \leq 0.05$ ) ammonical-nitrogen (AN) removal compared to control. Based on biochemical tests, the strain was identified as Microbacterium sp. Strain VCM11 was inhibited in all the antibiotic tests (troleandomycin, rifamycin SV, lincomycin, and nalidixic acid). Different parameters including sodium chloride $(\mathrm{NaCl})$ concentration and temperatures were tested. The results obtained indicated that $\mathrm{VCM} 11$ at $180 \mathrm{rpm}, 30^{\circ} \mathrm{C}$, and $35 \mathrm{ppt}$ of sodium chloride $(\mathrm{NaCl})$ reduced $53.57 \pm 3.16 \mathrm{NH} 3+-$ $\mathrm{N}$ to $4.83 \pm 1.12 \mathrm{NH} 3+-\mathrm{N}(90.98 \%)$ within 120 hours.
\end{abstract}

(Keywords: water quality, ammonia content (AC), Microbacterium sp., biochemical tests and antibiotic tests)

\section{INTRODUCTION}

The management of water quality in aquaculture and particularly in hatcheries is essential. Deterioration of water quality particularly with high total ammonia nitrogen (TAN) will affect the productivity of aquaculture. User and environmentally friendly technologies such as bioremediation are being adopted in aquaculture farms to manage water quality. Ammonia concentration is one of the crucial factors determining aquaculture water quality. Ammonia excretion rate has been used to assess the effects of various factors on total nitrogen excreted by crustaceans due to ammonotelism (Jiang et al., 2000). Ammonia exists in two different forms, ionized $\left(\mathrm{NH}_{4}{ }^{+}\right)$and unionized $\left(\mathrm{NH}_{3}\right)$. Unionized ammonia $\left(\mathrm{NH}_{3}\right)$ induces stress to aquatic animals and results in decreased survival of aquatic organisms (Millamena, 1990). Unionized ammonia $\left(\mathrm{NH}_{3}\right)$ is considered more toxic than ionized ammonia $\left(\mathrm{NH}_{4}{ }^{+}\right)$due to its ability to diffuse readily across the cell membrane (Emerson et al., 1985). Therefore, the removal of ammonia is crucial to hatcheries that produce cultured organisms.

There are three possible processes (physical, chemical, and biological) of remediation used to remove ammonia in the aquaculture system (Barik et al., 2011). The physical process has limits to application and is expensive. Chemical remediation involves application of chemicals to reduce the ammonia concentration. Some of the chemicals used may itself be harmful to the organisms if they accumulate in culture systems. Biological remediation is an important tool to convert toxic substance to non-toxic substance.

Biological nitrification-denitrification is one of the solutions to reduce the ammonia concentration in aquaculture. This process is technically feasible and economically favourable (Peng and Zhu, 2006). There are various methods and techniques developed for the nitrification and denitrification of aquaculture wastewater. These include sequencing batch reactor (SBR) (Fontenot et al., 2007; Guo et al., 2011), hydrogenotrophic denitrification of synthetic aquaculture wastewater using membrane reactor (Visvanathan et al., 2008), aerobic and anaerobic biofiltration (Rijn and Rivera, 1990), bio-electrochemical removal (Ghafari et al., 2008), and trickling filter using different filter media (Lekang, 2000). All these methods and techniques have varying degrees of success. Removal of TAN under conditions of continuous TAN production is not an easy task (Shan and Obbard, 2001). Further technical problems during designation, maintenance of the technology, and high capital cost restrict the efficiency in reducing ammonia concentration (Shan and Obbard, 2001). 
Since extensive and sophisticated wastewater treatment methods are very expensive and unsuitable for wastewater treatment, an effective, inexpensive, and safe biological water treatment would be more beneficial. The aim of this study was to isolate and screen indigenous bacteria suitable for treating the aquaculture wastewater.

\section{MATERIAL AND METHODS}

\section{Isolation and screening of bacteria}

Ammonium oxidizing bacteria (AOB) media was prepared by dissolving $5 \mathrm{~g}$ of peptone, $3 \mathrm{~g}$ of beef extract, $1 \mathrm{~g}$ of potassium nitrate $\left(\mathrm{KNO}_{3}\right)$, and $20 \mathrm{~g}$ of sodium chloride $(\mathrm{NaCl})$ in $1 \mathrm{~L}$ of distilled water. The AOB medium was autoclaved for $15 \mathrm{~min}$ at $121^{\circ} \mathrm{C}$. Sterile medium $(100 \mathrm{~mL})$ in $250-\mathrm{mL}$ conical flasks $(\mathrm{n}=3)$ was inoculated with $5 \mathrm{~mL}$ of aquaculture wastewater (7 days without water exchange) collected from Marine Culture Unit, University Malaya, and incubated at $30^{\circ} \mathrm{C}$ on a rotary shaker at 180 rotations per minute (rpm). After 7 days of incubation, $1 \mu \mathrm{L}$ of sample spread on fresh agar plates. After 48 hours, single colonies were picked and streaked on fresh $\mathrm{AOB}$ agar plates. Pure isolates were obtained by repeated streaking on fresh agar plates. The resulting bacterial isolates were tested for their ability to produce nitrite by using nitrate reduction test kit (SigmaAldrich Chemie GmbH, Switzerland). Nine grams of nitrate broth powder were dissolved in $1 \mathrm{~L}$ of distilled water. Ten $\mathrm{mL}$ of the broth was dispensed into $20 \mathrm{~mL}$ sample tubes and autoclaved at $121^{\circ} \mathrm{C}$ for 15 minutes and cooled. One $\mathrm{mL}$ of bacterial sample was then inoculated into three sample tubes. A negative control (autoclaved wastewater) was set up. All the tubes were incubated at room temperature for $48 \mathrm{~h}$. Five drops of reagent A (sulfanilic acid solution) and 5 drops of reagent $B$ ( $\alpha$ - naphthylamine solution) were added into all the tubes.

\section{Treatment of wastewater by selected strain}

Out of 21 strains, nine strains were screened for on their ability to produce nitrite. All nine strains were screened for ammonia reduction in aquaculture wastewater collected from Marine Culture Unit, University Malaya. Ammonia concentration was analysed by photometric determination (Hach spectrophotometer DR2400, USA) with ammonia salicylate reagent, ammonia cyanurate reagent and AmVer ${ }^{\text {TM }}$ high range ammonia test ' $\mathrm{N}$ tube ${ }^{\mathrm{TM}}$ reagent (Hach, Loveland, USA). The strain that showed better reduction of ammonia was selected for further analysis.

\section{Biochemical Identification}

Strain VCM11 was selected due to its significant reduction $(p \leq 0.05)$ of ammonia concentration compared to the rest. Biochemical test for strain VCM11 was based on morphological, physiological, and biochemical characteristics. Gram staining of strain VCM11 was carried out to determine whether it was Gram negative or Gram positive. The carbon utilization test was performed with 15 different carbons. The bacterium was identified according to Bergey's Manual of Determinative Bacteriology.

\section{Effect of temperature on growth}

Temperature plays an important role for the optimum growth of a bacterium. The effect of temperature on growth of strain VCM11 was studied by incubating the culture media at temperatures $25^{\circ} \mathrm{C}, 30^{\circ} \mathrm{C}, 37^{\circ} \mathrm{C}$, and $40^{\circ} \mathrm{C}$. The optical density (OD) read at $600 \mathrm{~nm}$ was recorded after $48 \mathrm{~h}$ for all temperatures tested.

\section{Effect of Sodium Chloride on growth}

The effect of $\mathrm{NaCl}$ for best growth of strain VCM11 was studied by supplying various concentrations of $\mathrm{NaCl}$ to the production medium. The experiment was carried out separately for various concentrations of $\mathrm{NaCl}$ namely 10ppt, 35ppt, 50ppt, and 65ppt. The optical density (OD) reading at $600 \mathrm{~nm}$ was recorded at $48 \mathrm{~h}$ after incubation for all the $\mathrm{NaCl}$ concentrations.

\section{Statistical Methods}

All tests were conducted in triplicates. Two-way analysis of variance (ANOVA) was applied to assess the difference in each parameter among treatments using the SPSS 17.0 statistical software package. $\mathrm{P} \leq 0.05$ was taken to indicate statistical significance at $95.0 \%$ confidence level.

\section{RESULTS}

Isolation, selection, and treatment of strain VCM11 
Out of 21 isolates, 9 strains gave good results. Strain VCM11 was selected based on its excellent reduction of ammonia concentration in the aquaculture wastewater and detection of nitrite. Appearance of distinct red colour from the nitrite indicates nitrate reduction. Figure 1 shows the ammonia concentration of control (wastewater without autoclaving) and wastewater inoculated with bacteria (VCM11) for 120 h. Strain VCM11 reduced $90.98 \%$ of ammonia concentration within $120 \mathrm{~h}$ compared to control $(24.91 \%)$.

\section{Identification of strain VCM 11}

Strain VCM11 was characterized by plating on nitrate agar. It was found to be aerobic, Grampositive, and rod-shaped bacterium. The physiological and biochemical characteristics are summarized in Table 1. Based on morphological, physiological, and biochemical characteristics, strain VCM11 was identified as Microbacterium sp.

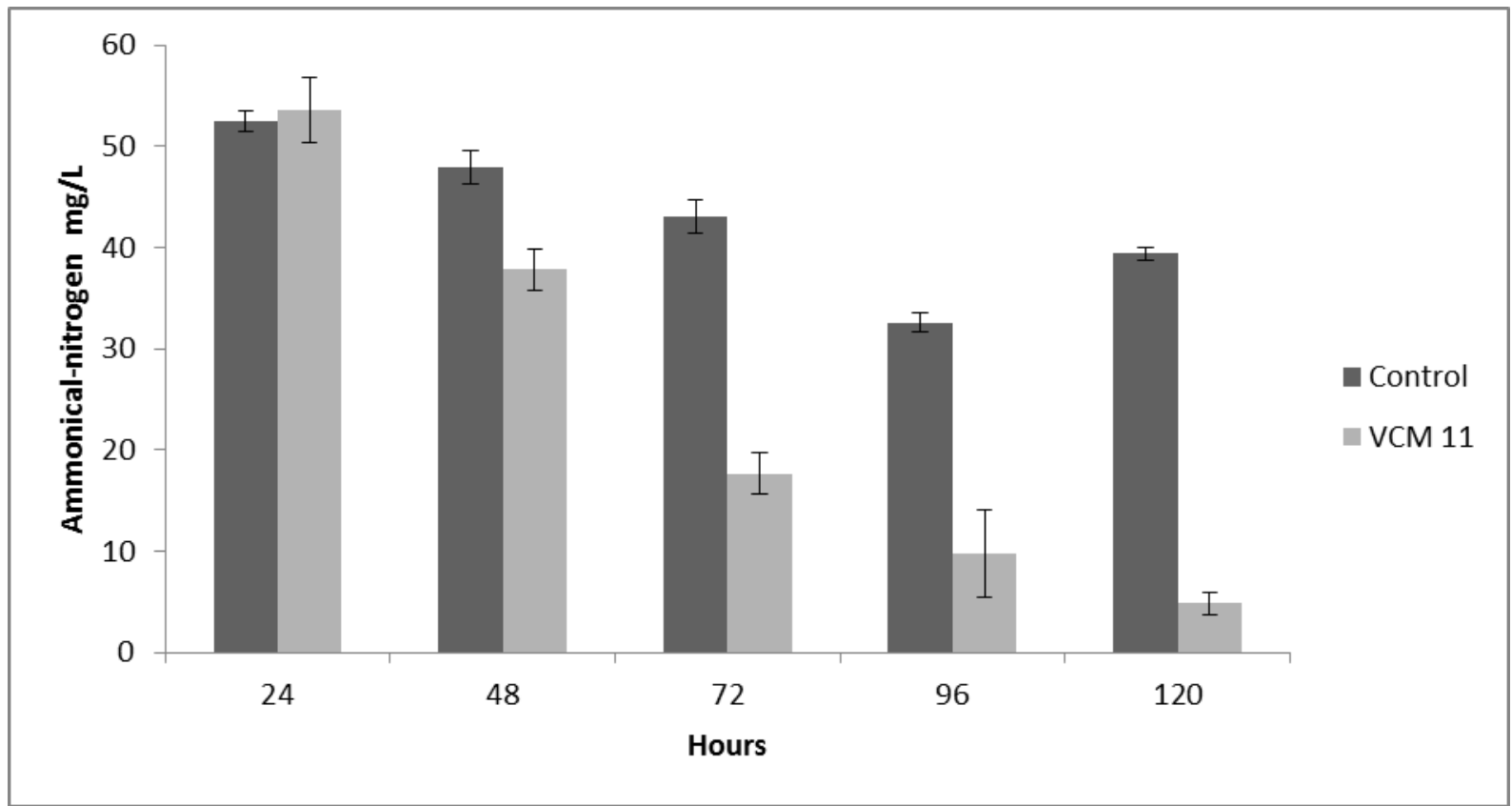

Figure 1. Concentrations of ammonical-nitrogen $\left(\mathrm{NH}_{3}{ }^{+}-\mathrm{N}\right) \mathrm{mg} / \mathrm{L}$ in control and treatment (autoclaved wastewater with bacterium VCM11). Number of replicates (n) $=3$. 
Table 1: Morphological and biochemical characteristics of strain VCM 11

\begin{tabular}{rc}
\hline Biochemical test & Results \\
\hline Gram's staining & Positive \\
Carbon source: & \\
D-Maltose & + \\
D-Trehalose & + \\
Sucroce & + \\
D-Raffinose & - \\
$\alpha-$ D-Lactose & + \\
D-Melibiose & + \\
$\alpha-$ D-Glucose & + \\
D-Mannose & + \\
D-Fructose & + \\
D-Galactose & + \\
L-Rhamnose & + \\
Inosine & + \\
D-Sorbitol & - \\
D-Mannitol & - \\
Glycerol & + \\
Antibiotic resistance test: & \\
Troleandomycin & - \\
Rifamycin SV & - \\
Lincomycin & - \\
Nalidixic Acid & - \\
\hline Positive results, - Negative reslts
\end{tabular}

+ Positive results, - Negative results

\section{Effect of Sodium Chloride ( $\mathrm{NaCl})$ on growth}

Figure 2, shows the effect of $\mathrm{NaCl}$ on the growth of strain VCM11 based on optical density (OD), after an incubation period of $48 \mathrm{~h}$ at room temperature. Its halotolerant nature was observed. Among the tested concentrations of $\mathrm{NaCl}$, the optimum growth $\left(\mathrm{OD}_{600 \mathrm{~nm}}=0.316\right)$ was observed at 35ppt $\mathrm{NaCl}$ supplemented AOB medium.

\section{Effect of temperature on bacterium density}

Temperature is one of the most critical parameters that have to be controlled in bioremediation. Figure 3 shows the effect of temperature on optical density (OD) of strain VCM11 at 35ppt $\mathrm{NaCl}$ after $48 \mathrm{~h}$. Strain VCM11 showed optimum growth at $30^{\circ} \mathrm{C}$ with $0.943 \mathrm{OD}$ at $600 \mathrm{~nm}$.

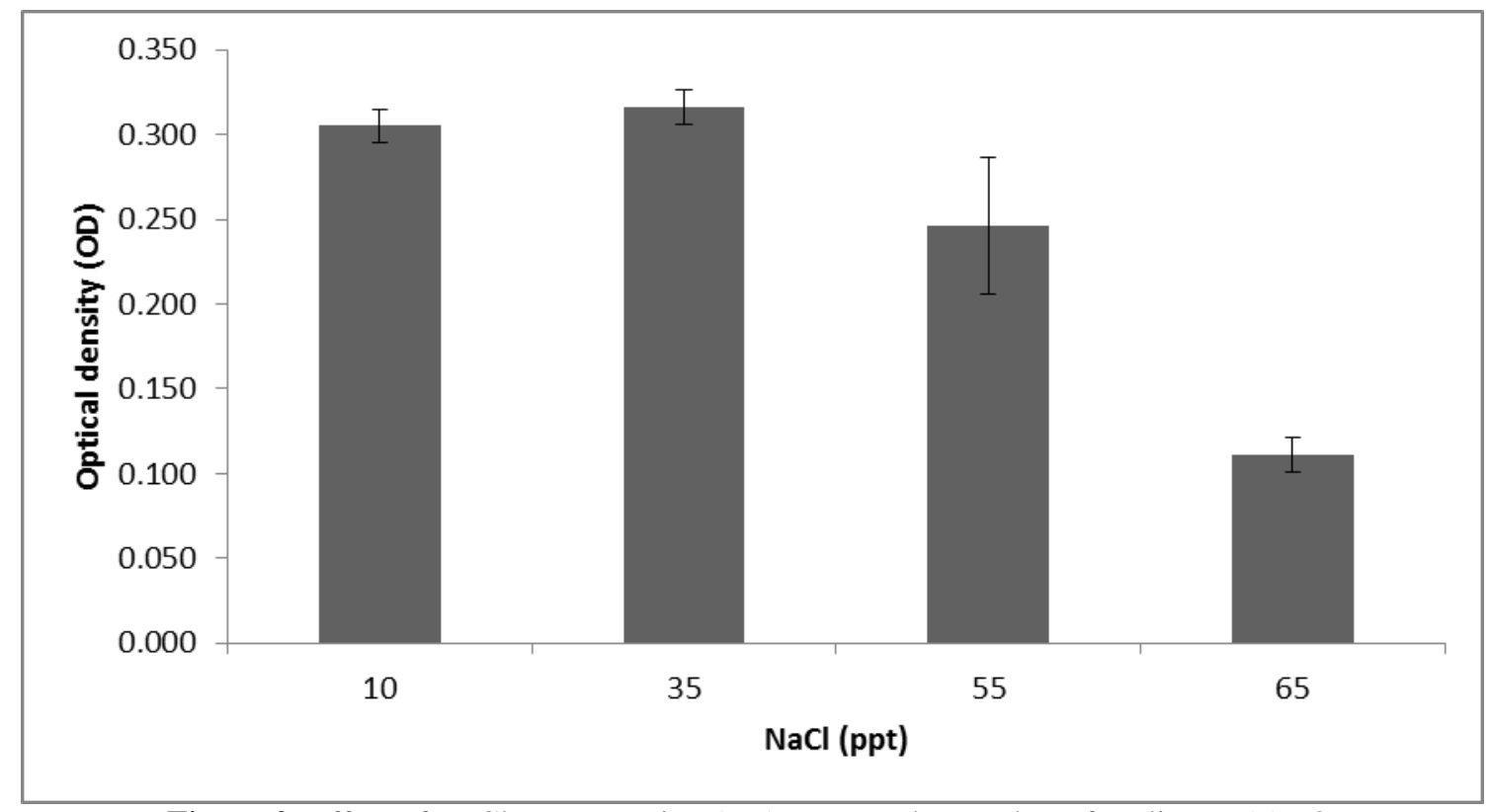

Figure 2. Effect of $\mathrm{NaCl}$ concentration (ppt) on growth. Number of replicates $(\mathrm{n})=3$. 


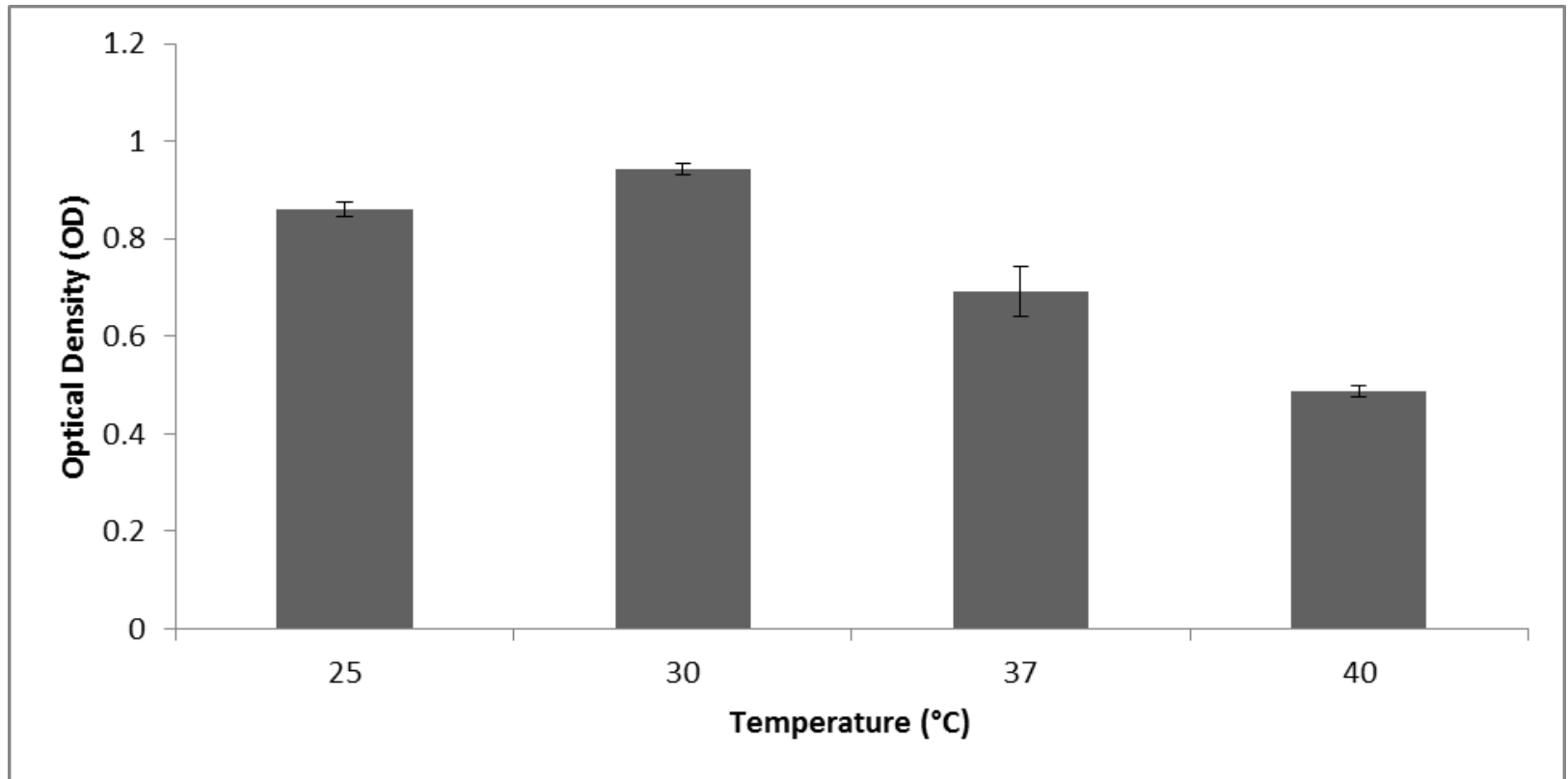

Figure 3. Effect of temperature $\left({ }^{\circ} \mathrm{C}\right)$ on optical density (OD) at $600 \mathrm{~nm}$. Number of replicates $(\mathrm{n})=3$.

\section{DISCUSSION}

Microbacterium sp., VCM11 isolated from aquaculture wastewater showed significant reduction of ammonia concentration $(\mathrm{p} \leq 0.05)$ compared to control. The control in this experiment represents the untreated aquaculture wastewater without the addition of any bacteria or adjustment in parameters. Treatment experiments were carried out with 25 percent inoculums of Microbacterium sp., VCM11 into the autoclaved aquaculture wastewater. The ammonia content in the treated wastewater $(90.98 \%$ within $120 \mathrm{~h})$ gradually decreased as compared to the control $(24.91 \%)$. Since high ammonia concentration is toxic to aquatic organisms, the pathway which lead to the formation of gaseous nitrogen are ideal in culture systems (Barik et al., 2011). In the aquaculture system, the nitrification process takes a longer period to oxidize ammonia to nitrite due to the high nutrient load resulting in hypoxia (Jørgensen, 1996). According to Boyd and Ahmad, 1987, denitrifying bacteria such as Pseudomonas and Acinetobacter utilize the nitrate molecules as electron acceptor during reduced oxygen tension. Microbacterium sp., VCM11 worked well to reduce ammonia.

Microbacterium sp. VCM11 has its own merit with respect to reduced interspecific competition and lesser growth inhibition. The use of indigenous bacteria reduces the inter-specific competition and takes shorter acclimation period
(Shan and Obbard, 2001). Non-indigenous bacteria are not recommended for bioaugmentation as they will be edge out by the competing native microorganisms (Stephenson and Stephenson, 1992)Hence, increasing the cell density of such beneficial bacteria in wastewater reduces the toxic ammonia level safely and effectively.

Biochemical tests were performed to identify the species. Microbacterium sp. VCM11 is not resistant to troleandomycin, rifamycin SV, lincomycin, and nalidixic acid. Antibiotic resistance tests are important to ensure that the microorganisms used do not contain transferable antimicrobial resistance determinants (Matto et al., 2007). Carbon utilization tests (CUS), as used for the classification and identification of bacteria (Koser, 1923), have shown that Microbacterium sp. VCM11 can utilize Dmaltose, D-trehalose, sucrose, $\alpha-\mathrm{D}$-lactose, Dmelibiose, $\alpha$ - D-glucose, D-mannose, Dfructose, D-galactose, L-rhamnose, inosine, and glycerol.

Temperature and salinity are two major environmental factors in aquaculture systems (Jiang et al, 2000). Microbacterium sp. VCM11 shows optimum growth at $30^{\circ} \mathrm{C}$ and $35 \mathrm{ppt}$ of $\mathrm{NaCl}$. The optical density value at $600 \mathrm{~nm}$ for $35 \mathrm{ppt} \mathrm{NaCl}$ was 0.316 . Better growth was observed $(0.943$ optical density at $600 \mathrm{~nm})$ when the temperature was optimized with $35 \mathrm{ppt} \mathrm{NaCl}$. However, there is no significant difference 
$(p \geq 0.05)$ within the range of $10-35 \mathrm{ppt} \mathrm{NaCl}$. Therefore, this strain shows a good range of tolerance towards sodium chloride concentration (seawater). Temperature of $25^{\circ} \mathrm{C}-30^{\circ} \mathrm{C}$ shows similar correlation with sodium chloride concentration, resulting in no significant difference $(p \geq 0.05)$ for this range. Since this strain can withstand such ranges (10-35ppt of $\mathrm{NaCl}$ and $25^{\circ} \mathrm{C}-30^{\circ} \mathrm{C}$ ), for cost effectiveness, natural concentration of seawater and room temperature would be sufficient to provide an optimum results.

\section{CONCLUSION}

Microbacterium sp. VCM11 can be used as a biological tool to reduce ammonia concentration in aquaculture wastewater. The bacterium is able to remove $91 \%$ of $\mathrm{NH}_{3}{ }^{+}-\mathrm{N}$ concentration after $120 \mathrm{~h}$ of growth.

\section{ACKNOWLEDGEMENT}

The work was supported by the research grant PPP 2012, (PV007/2012A) from University of Malaya and Ministry of Science, Technology, and Innovation (MOSTI) Science Fund (53-0203-1024). We thank the anonymous reviewers for their critical evaluation of the manuscript.

\section{REFERENCES}

1. Barik, P., Vardia, H. K., and Gupta, S. B.2011. Bioremediation of ammonia and nitrite in polluted water. International Journal, 3(July), 135-141.

2. Bergey's Manual of Systematic Bacteriology. Vol.4. Williams,S.T. (ed.) Baltimore: Williams and Wilkins, $\mathrm{p}$ 2340-2343.

3. Emerson, K, Russo, R.C., Lund, R.E., and Thurston, R.V. 1975. Aqueous ammonia equilibrium calcilations: Effect of $\mathrm{pH}$ and temperature. J.Fish.Res.Bd Canada, 32 (2): 3792388.

4. Fortenot, Q., Bonvillain, C., Kilgen, M. and Boopathy., R. 2006. Effects of temperature, salinity and carbon: nitrogen ratio on sequencing batch reactor treating shrimp aquaculture wastewater. Bioresource Technology, 98 (2007) 1700-1703.
5. Ghafari, S., Hassan, M., and Aroua, M.K.2008. Bio-electrochemical removal of nitrate from water and wastewater-A review. Bioresource Technology. 99(10): 3965-3974.

6. Guo, F., Zhang, S.H., Yu, X., and Wei, B. 2011. Variations of both bacterial community and extracellular polymers: The inducements of increase of cell hydrophobicity from biofloc to aerobic granule sludge. Bioresource Technology, 102 (11): 6421-6428.

7. Jiang, D.H., Lawrence, A.L., Neill, W.H., and Gong, H. 2000. Effects of temperature and salinity on nitrogenous excretion by Liptopenaeus vannamei juveniles. Journal of Experimental Marine Biology and Ecology, 253: 193209.

8. Jørgensen,B.B.1996. Material flux in the sediment. In: Jørgensen, B.B., and Richardson, K. (eds) Eutrophication in coastal marine ecosystems. Coastal and estuarine studies 52. American Geophysical Union, Washington, p 115135.

9. Koser, S.A.1923.Utilization of the salts and organic acids by the colonaerogenes group. Journal of Bacteriology, $\quad 8: \quad 493-520$.

10. Lekang, O.I., and Kleppe, H. 2000. Efficiency of nitrification in trickling filters using different filter media. Aquacultural Engeneering. 21(3): 181199.

11. Matto, J., Angela, van Hoek, H.A.M , Domig, K.J., Saarelaa, M., Belén Flórez, A., Brockmanne, E., Amtmanne, E, Mayo, B., Aarts, H.J.M. and Danielsen, M., 2007. Susceptibility of human and probiotic Bifidobacterium spp. to selected antibiotics as determined by the Etest method. International Dairy Journal, 17: 11231131.

12. Millamena, O.M. 1990. Organic pollution resulting from excess feed and metabolite build- 
13. up: effect of Penaeus monodon postlarvae. Aquacultural Engineering, 9:

14. Shan, H., and Obbard, J. P. (2001). Ammonia removal from prawn aquaculture water using immobilized nitrifying bacteria. Applied Microbiology and Biotechnology, 791798.

15. Stephenson, D., and Stephenson, T. (1992). Bioaugmentation for enhancing biological wastewater treatment. Biotechnology Advances, 10:549-559.

16. Rijn, J.V., and Rivera, G. 1990. Aerobic and anaerobic biofiltration in an aquaculture unit-Nitrite accumulation as a result of nitrification and denitrification. Aquacultural Engeneering, 9 (4): 217-234.

17. Peng, Y. and Zhu, G. 2006. Biological nitrogen removal with nitrification and denitrification via nitrite pathway. Applied Microbiology and Biotechnology, 73(1): 15-26.

18. Visvanathan, C. Hung, N.Q., and Jegatheesan, 2008. Hydrogenotrophic denitrification of synthetic aquaculture wastewater using bioreactor. Process Biochemistry, 43(6): 673-682. 